\title{
Ultra-violet radiation is responsible for the differences in global epidemiology of chickenpox and the evolution of varicella-zoster virus as man migrated out of Africa
}

Philip S Rice

\begin{abstract}
Background: Of the eight human herpes viruses, varicella-zoster virus, which causes chickenpox and zoster, has a unique epidemiology. Primary infection is much less common in children in the tropics compared with temperate areas. This results in increased adult susceptibility causing outbreaks, for example in health-care workers migrating from tropical to temperate countries. The recent demonstration that there are different genotypes of varicellazoster virus and their geographic segregation into tropical and temperate areas suggests a distinct, yet previously unconsidered climatic factor may be responsible for both the clinical and molecular epidemiological features of this virus infection.
\end{abstract}

Presentation of the hypothesis: Unlike other human herpes viruses, varicella-zoster virus does not require intimate contact for infection to occur indicating that transmission may be interrupted by a geographically restricted climatic factor. The factor with the largest difference between tropical and temperate zones is ultra-violet radiation. This could reduce the infectiousness of chickenpox cases by inactivating virus in vesicles, before or after rupture. This would explain decreased transmissibility in the tropics and why the peak chickenpox incidence in temperate zones occurs during winter and spring, when ultra-violet radiation is at its lowest. The evolution of geographically restricted genotypes is also explained by ultra-violet radiation driving natural selection of different virus genotypes with varying degrees of resistance to inactivation, tropical genotypes being the most resistant. Consequently, temperate viruses should be more sensitive to its effects. This is supported by the observation that temperate genotypes are found in the tropics only in specific circumstances, namely where ultra-violet radiation has either been excluded or significantly reduced in intensity.

Testing the Hypothesis: The hypothesis is testable by exposing different virus genotypes to ultra-violet radiation and quantifying virus survival by plaque forming units or quantitative mRNA RT-PCR.

Implications of the hypothesis: The ancestral varicella-zoster virus, most probably a tropical genotype, comigrated with man as he left Africa approximately 200,000 years ago. For this virus to have lost the selective advantage of resistance to ultra-violet radiation, the hypothesis would predict that the temperate, ultra-violet sensitive virus should have acquired another selective advantage as an evolutionary trade-off. One obvious advantage could be an increased reactivation rate as zoster to set up more rounds of chickenpox transmission. If this were so, the mechanism responsible for resistance to ultra-violet radiation might also be involved in reactivation and latency. This could then provide the first insight into a genetic correlate of the survival strategy of this virus.

Correspondence: price@sgul.ac.uk

Department of Medical Microbiology, St George's Hospital, Blackshaw Road, London, SW17 OQT, UK 


\section{Background}

Chickenpox epidemiology is unique among human herpes viruses. In the tropics primary infection is often delayed into later childhood whereas in temperate zones most infection occurs before leaving school. Indeed, in some tropical countries $30-50 \%$ of adults are susceptible, compared with only $5-10 \%$ from temperate areas [1].

Conventionally, transmission has been considered to occur by shedding of virus from the upper respiratory tract 1-2 days before the rash $[2,3]$. The papers which claim to show such virus transmission however, also conclude that the titres of virus in vesicular fluid are considerably greater than those present in the pharynx and that vesicular virus makes the greatest contribution to spread [4-6]. Indeed, the few papers cited as providing epidemiological evidence for airborne spread are either mis-quoted [7], based on case reports [8,9] or do not reflect the normal transmission environment [10]. In this regard chickenpox appears similar to smallpox, which also had a distinct winter-spring seasonal peak in incidence and was spread partly by the vesicular eruption [11].

Why such a common, global infection should be less common in children from the tropics when infections are generally more common remains unknown. Although previously suggested factors such as heat, humidity, viral interference, population density or infection with crossprotecting viruses, have been suggested as possible causes of the epidemiological differences, a unified, coherent explanation has eluded discovery $[1,12]$. The climatic factor which I propose to show is responsible for the geographical differences in transmission is ultra-violet radiation (UVR). Furthermore, as varicella-zoster virus (VZV) exists only in man, I propose that UVR has been involved in the co-evolution of virus as man migrated out of Africa. The evolution of varying degrees of resistance to UVR among the different genotypes [13] may also have implications for virus reactivation as zoster.

\section{Presentation of the hypothesis}

A search for sero-epidemiological studies of varicellazoster virus (VZV) using the terms "varicella", "chickenpox" and "seroepidemiology" produced a total of 25 papers. From these publications other relevant references were also located giving a total of 42 articles, reviewed in [14]. Whilst the studies were of different formats, linear regression curves of age-stratified antibody prevalence plotted against latitude showed a reasonably good fit $\left(\mathrm{r}^{2} \approx 0.5\right)$ was demonstrated across all age groups of children $>5$ years (Figure 1 ). The same antibody prevalence data when plotted against temperature, rainfall, population density and sunshine, using data drawn from the World Meteorological Organisation (http://www.wmo.int) and the United Nations (http:// www.fao.org/WAICENT/FAOINFO/SUSTDEV/EIdirect/ CLIMATE/EIsp0002.htm), showed no consistent correlation (Figures 2, 3, 4 and 5).

Chickenpox is seasonal in temperate zones, with the highest incidence seen in winter and spring [1]. One explanation for this seasonality could be the significantly higher levels in ultra-violet radiation (UVR) of approximately 10-25-fold seen in summer in temperate zones [15], which could inactivate virus either in vesicular lesions or after their rupture. Chickenpox is not seasonal in the same way in the tropics possibly because UVR differs only by a factor of two during the year [15]. The tropics however, do experience peaks in chickenpox incidence when the climate is hot, dry and sunny with a rapid decline to very low levels during the rainy season [16-18]. This appears difficult to reconcile with UVR inactivating virus until the effects of atmospheric pollution on ambient UVR are considered. For example, the Indo-Asian haze, a continent-wide increase in air pollution during the dry season from December to April, has been shown to reduce significantly the level of ambient UVR [19]. As the Monsoon arrives, atmospheric particles and pollutants are washed out, increasing the UVR which inactivates virus more effectively. This correlates very well with the observed chickenpox incidence in Sri Lanka and south India $[16,17]$. Furthermore, outbreaks of varicella have been terminated in certain African countries by the arrival of the rainy season [18]. Increased atmospheric pollution might partly explain, in association with locally increased population density, why chickenpox is commoner in urban environments compared with rural communities in adjacent geographic areas [20,21].

Further support for the hypothesis derives from sequence analysis which has classified VZV into distinct genotypes. In the largest published study, 348 genotypes of VZV were given geographic locations based on where the virus was originally detected [13]. In the temperate zones which were studied (N America, Argentina, Europe, S Africa, N China, N Asia) a total of $35 / 259$ (13.5\%) genotypes were tropical. In contrast, of the 89 isolates from tropical countries/ regions (India, Nepal, Bangladesh, Chad, DRC, Southern China, Western Australia, Brazil, Cote D' Ivoire, Ethiopia, Thailand, Vietnam, Zimbabwe), only 5 (5.6\%) were temperate. This difference was statistically significant by Chi-square testing $(\mathrm{p}<0.0001)$. Nevertheless, temperate virus genotypes, which should be more sensitive to UVR than tropical strains, and so would be out-competed in terms of transmission, have been detected in tropical areas, namely Australia, Brazil, Congo, and Mexico City. However, survival of temperate genotypes in these regions is still consistent 


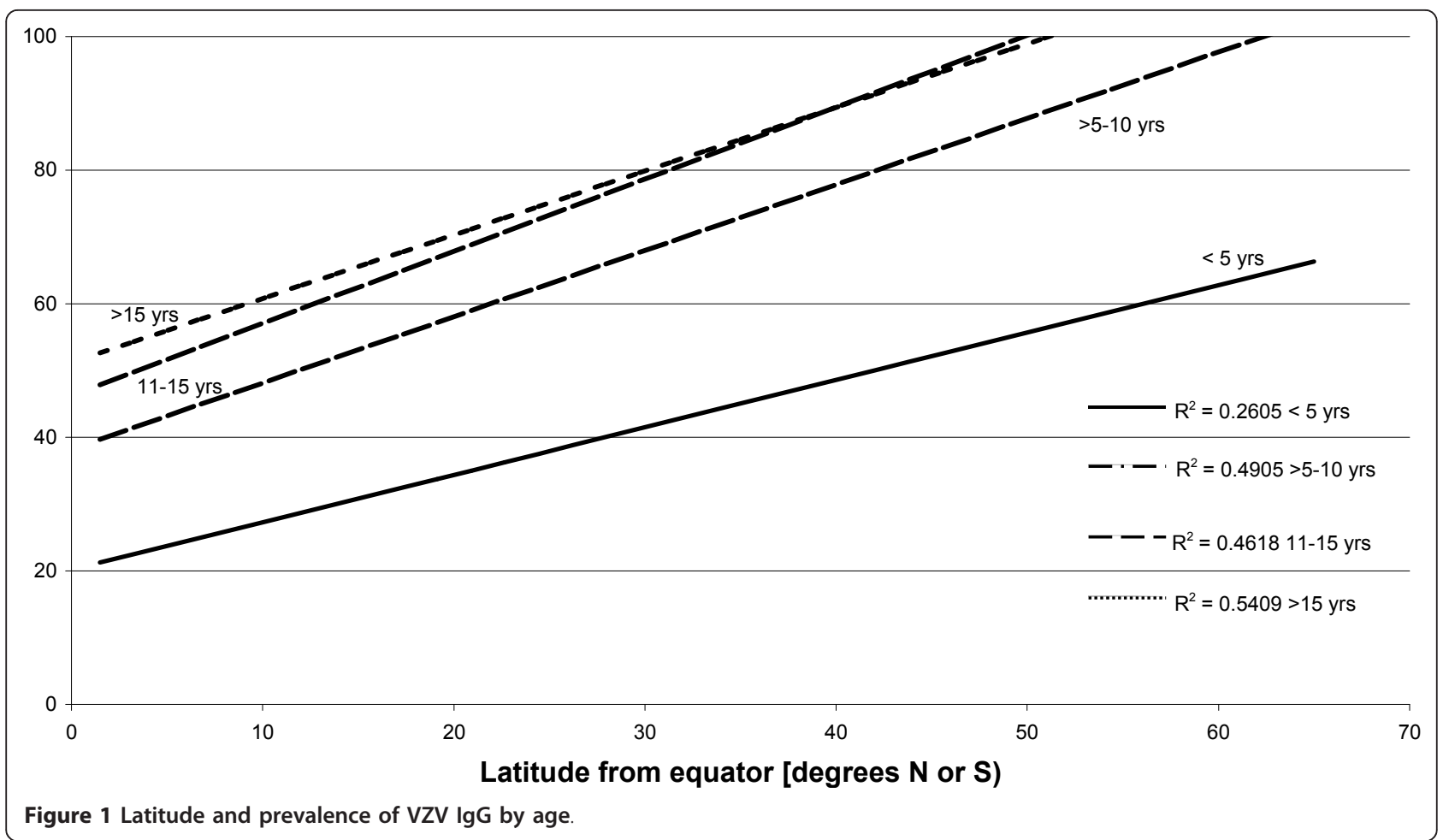

with the hypothesis when it is considered how reducing ambient UVR allows temperate genotypes to transmit.

In Australia widespread preventative measures are taken limit exposure to UVR in schools by having large, shaded playground areas.
In urban Brazil, man-made biomass burning and in rural areas, the forest canopy and high humidity act together to reduce UVR [22].

In the Congo, the first ever demonstration of transmission of temperate virus, occurred in only one family all living in the same house, the implication being that

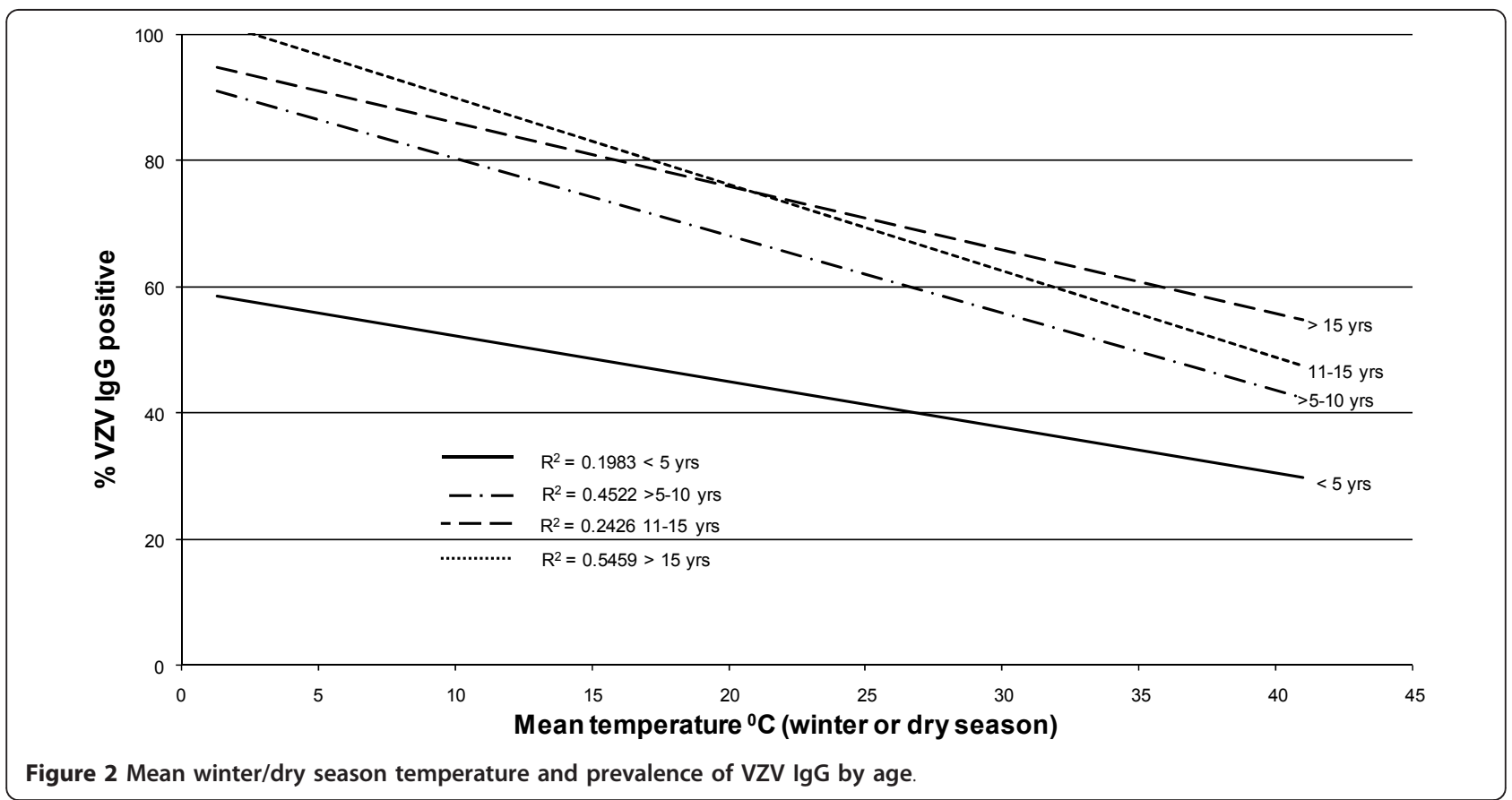



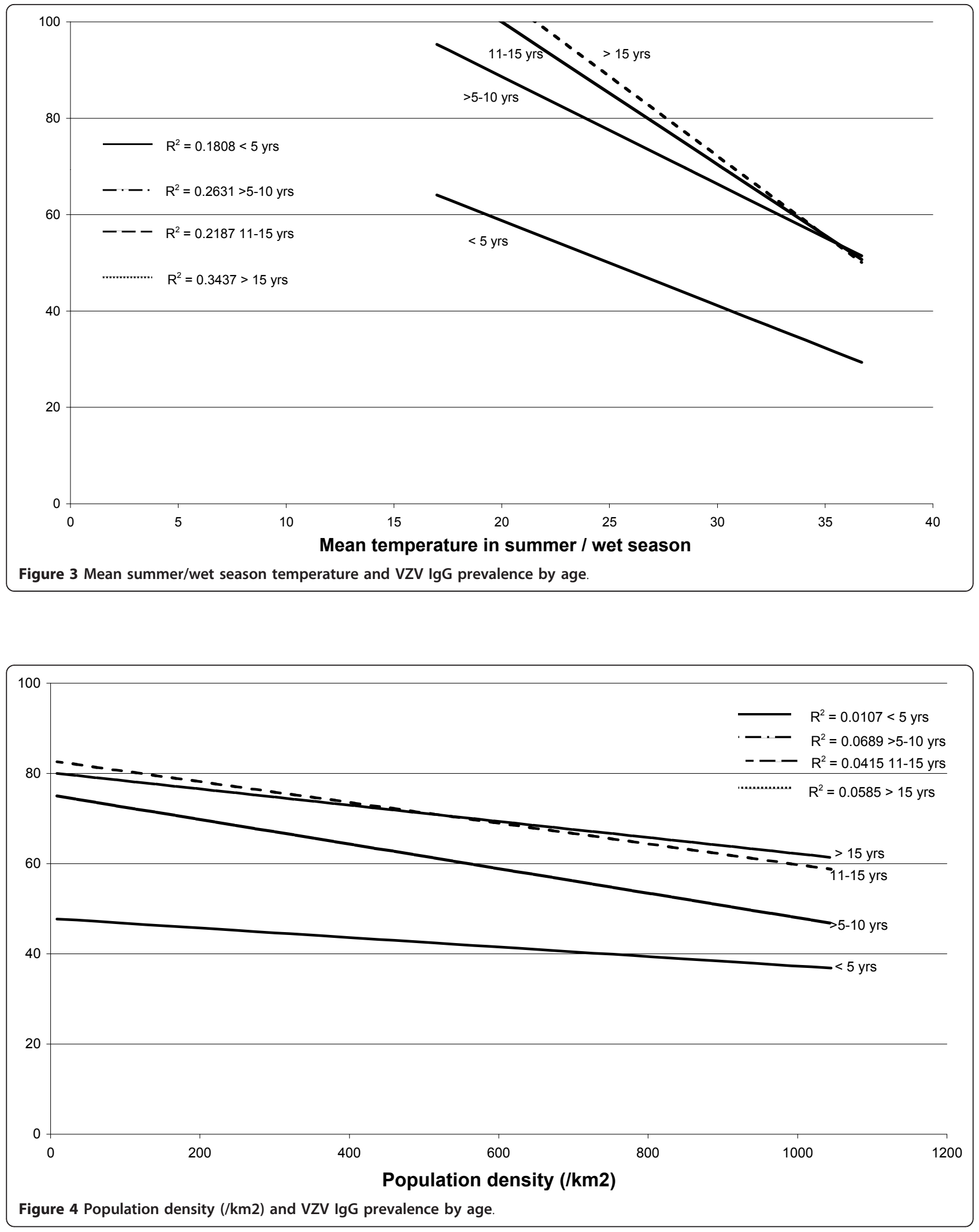


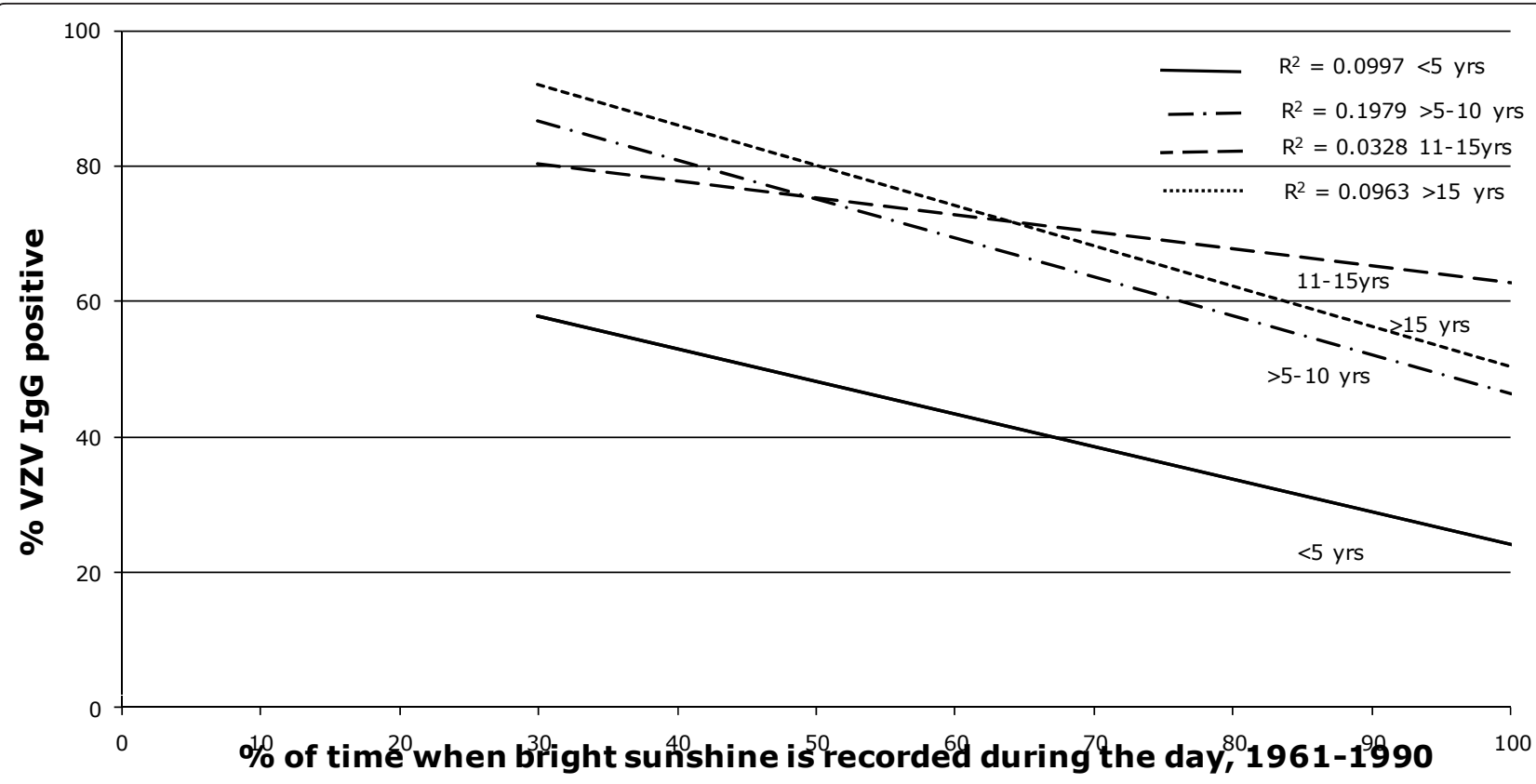

Figure 5 Mean annual sunshine fraction (1961-1990), \% of time with bright sunshine and age stratified VZV IgG sero-prevalence.

temperate virus is rapidly inactivated by UVR after leaving the confines of the family home [23].

Finally, the detection of temperate virus genotypes from cases of chickenpox in Mexico City may be explained because it is one of the most heavily polluted cities in the world which reduces UVR, allowing temperate genotypes to survive [24].

\section{Proving the hypothesis}

The hypothesis is biologically plausible because UVR is virucidal against many viruses, yet the effect of UVR on survival of VZV in vitro has never been tested [25]. However, the effect of UVR on virus transmission in vivo was demonstrated over 60 years ago when artificial UVR was used successfully to reduce virus transmission in US schools to limit spread of chickenpox [26]. Epidemiological evidence to support the hypothesis could be provided by correlating the transmission of different virus genotypes with ambient UV radiation. Genotyping VZV in cases of chickenpox could determine if there are seasonal differences in genotype transmission in temperate areas. The hypothesis would predict that tropical virus genotypes should predominate during summer in temperate countries since they would have the selective advantage of increased resistance to UVR.

If different genotypes of VZV possess different tolerances to UVR this could be demonstrated in vitro by exposing virus to UVR and quantifying the surviving virus by either plaque forming units or quantitative mRNA RTPCR. Finally, it may also be possible to make hybrid viruses by exchanging those regions of the VZV genome which are significantly different between genotypes and determine for the first time the molecular markers that underlie transmission or reactivation of VZV.

\section{Implications of the hypothesis}

The principal difficulty with the hypothesis is explaining how an ancestral tropical virus genotype, inherently more resistant to UVR, migrated with man out of Africa 200,000 years ago only to lose the selective advantage of resistance to UVR, form a temperate virus genotype lineage and as result become less transmissible. The solution to this paradox could be that loss of the selective advantage of resistance to UVR and reduced transmissibility was offset by an increased propensity to reactivate as zoster. This could indicate that the areas of the VZV genome which confer resistance to UVR are the same as are involved in latency and reactivation.

I suspect this to be the case because as the transmission environment is so harsh in the tropics, random mutation and natural selection should have brought about a tropical virus genotype which reactivates much more frequently to counter-act the lower transmissibility of chickenpox. The fact that the data on zoster epidemiology from tropical countries (in the pre-AIDS era) are virtually absent suggests that the tropical genotype reactivates only in severely immune suppressed individuals. Potentially it may have implications for VZV vaccine since if it was made from a tropical genotype which reactivated much less frequently, it might be possible, in years to come, to significantly reduce the disease burden from zoster. 
List of abbreviations

UVR: Ultra-violet radiation; VZV: Varicella-zoster virus

\section{Authors' contributions}

Solely responsible for developing, researching and writing the hypothesis.

\section{Competing interests}

The authors declare that they have no competing interests.

Received: 19 December 2010 Accepted: 23 April 2011

Published: 23 April 2011

\section{References}

1. Varicella zoster virus: Virology and clinical management.Edited by: Arvin AA, Gershon AA. CUP; 2000.

2. Fenner $\mathrm{F}$ : The pathogenesis of the acute exanthems; an interpretation based on experimental investigations with mousepox; infectious ectromelia of mice. Lancet 1948, 2:915-20.

3. Grose C: Variation on a theme by Fenner: the pathogenesis of chickenpox. Pediatrics 1981, 68:735-7.

4. Ozaki T, Matsui Y, Asano Y, Okuno T, Yamanishi K, Takahashi M: Study of virus isolation from pharyngeal swabs in children with varicella. Am J Dis Child 1989, 143:1448-50.

5. Asano Y, Yoshikawa T, Ihira M, Furukawa H, Suzuki K, Suga S: Spread of varicella-zoster virus DNA to family members and environments from siblings with varicella in a household. 1999, 103:e61.

6. Sawyer MH, Wu YN, Chamberlin CJ, et al: Detection of varicella-zoster virus DNA in the oropharynx and blood of patients with varicella. J Infect Dis 1992, 166:885-8.

7. Gordon JR, Meader FM: The period of infectivity and serum prevention of chickenpox. JAMA 1929, 93:2013-15.

8. Evans P: An epidemic of chickenpox. Lancet 1940, ii:339-40.

9. Brunell PA: Transmission of chickenpox in a school setting prior to the observed exanthem. Am J Dis Child 1989, 143:1451-2.

10. Leclair JM, Zaia JA, Levin MJ, Congdon RG, Goldmann DA: Airborne transmission of chickenpox in a hospital. New Engl J Med 1980, 302:450-3.

11. Joarder AK, Tarantola D, Tulloch J: The eradication of smallpox from Bangladesh, New Delhi. Geneva, Switzerland: WHO Regional Publications; 1980.

12. Garnett GP, Cox MJ, Bundy DA, Didier JM, St Catharine J: The age of infection with varicella-zoster virus in St Lucia, West Indies. Epidemiol Infect 1993, 110:361-72.

13. Loparev VN, Gonzalez A, Deleon-Carnes M, et al: Global identification of three major genotypes of varicella-zoster virus: longitudinal clustering and strategies for genotyping. J Virol 2004, 78:8349-58.

14. Sengupta N, Breuer J: A global perspective of the epidemiology and burden of varicella-zoster virus. Curr Pediatr Rev 2009, 5:207-228.

15. Diffey BL: Solar ultraviolet radiation effects on biological systems. Phys Med Biol 1991, 36:299-328.

16. Maretic Z, Cooray MPM: Comparisons between chickenpox in a tropical and a European country. J Trop Med Hyg 1963, 66:311-5.

17. White E: Chickenpox in Kerala. Indian J Public Health 1978, 22:141-51.

18. Poulsen A, Cabral F, Nielsen J, et al: Varicella zoster in Guinea-Bissau. Intensity of exposure and severity of infection. Pediatr Infect Dis J 2005, 24:102-107.

19. Lelieveld J, Crutzen PJ, Ramanathan V, et al: The Indian Ocean experiment: widespread air pollution from South and Southeast Asia. Science 2001, 291:1031-6.

20. Mandal BK, Mukherjee PP, Murphy C, Mukherjee R, Naik T: Adult susceptibility to varicella in the tropics is a rural phenomenon due to the lack of previous exposure. J Infect Dis 1998, 178(Suppl 1):S52-4.

21. Liyanage NPM, Sirimali F, Malavige GN, et al: Seroprevalence of varicella zoster virus infections in Colombo district, Sri Lanka. Indian J Med Sci 2007, 61:128-134.

22. Mims FM: Significant reduction of UVB caused by smoke from biomass burning in Brazil. Photochem Photobiol 1996, 64:814-6.

23. Macneil A, Reynolds MG, Braden Z, et al: Transmission of atypical varicellazoster virus infections involving palm and sole manifestations in an area with monkeypox endemicity. Clin Infect Dis 2009, 48:e6-8.
24. Rodríguez-Castillo A, Vaughan G, Ramírez-González JE, et al: Genetic variation of Varicella-Zoster Virus strains circulating in Mexico City. J Clin Virol 2009, 46:349-53.

25. Lytle CD, Sagripanti JL: Predicted inactivation of viruses of relevance to biodefense by solar radiation. J Virol 2005, 79:14244-52.

26. Bahlke AM, Silverman HF, Ingraham HS: Effect of ultra-violet irradiation of classrooms on spread of mumps and chickenpox in large rural central schools. Am J Pub Hith 1949, 39:1321-1330.

doi:10.1186/1743-422X-8-189

Cite this article as: Rice: Ultra-violet radiation is responsible for the differences in global epidemiology of chickenpox and the evolution of varicella-zoster virus as man migrated out of Africa. Virology Journal 2011 8:189.

\section{Submit your next manuscript to BioMed Central and take full advantage of:}

- Convenient online submission

- Thorough peer review

- No space constraints or color figure charges

- Immediate publication on acceptance

- Inclusion in PubMed, CAS, Scopus and Google Scholar

- Research which is freely available for redistribution

Submit your manuscript at www.biomedcentral.com/submit
Ciomed Central 